\title{
Productivity and profitability of forage options for beef production in the subtropics of northern Australia
}

\author{
M. K. Bowen ${ }^{\mathrm{A}, \mathrm{C}}$, F. Chudleigh ${ }^{\mathrm{B}}$, S. Buck ${ }^{\mathrm{A}}$ and K. Hopkins ${ }^{\mathrm{A}}$ \\ ADepartment of Agriculture and Fisheries, PO Box 6014, Red Hill, Rockhampton, Qld 4701, Australia. \\ ${ }^{B}$ Department of Agriculture and Fisheries, Toowoomba, Qld 4350, Australia. \\ ${ }^{\mathrm{C}}$ Corresponding author. Email: maree.bowen@daf.qld.gov.au
}

\begin{abstract}
This study measured forage biomass production, diet quality, cattle liveweight gain, and economic performance of six forage types at 21 sites across 12 commercial beef cattle properties in the Fitzroy River catchment of Queensland during 2011-2014 (28 annual datasets in total). The forages were annual forage crops (oats (Avena sativa), sorghum (Sorghum spp.) and lablab (Lablab purpureus)), sown perennial legume-grass pastures (leucaena-grass (Leucaena leucocephala spp. glabrata + perennial, tropical grass $\left(\mathrm{C}_{4}\right)$ species) and butterfly peagrass (Clitoria ternatea + perennial, $\mathrm{C}_{4}$, grass species)), and perennial, $\mathrm{C}_{4}$, grass pastures. The sown forages resulted in 1.2-2.6 times the annual cattle liveweight gain per ha than perennial grass pastures. Annual cattle liveweight gain per ha, forage establishment and management costs, and cattle price margin (sale price less purchase price, $\$ / \mathrm{kg}$ liveweight) all influenced gross margin, however, none was an overriding factor. The average gross margins (\$/ha. annum) calculated using contractor rates, ranked from highest to lowest, were: leucaena-grass pastures, 181; butterfly pea-grass pastures, 140; oats, 102; perennial grass, 96; sorghum, 24; and lablab, 18. It was concluded that the tendency towards greater average gross margins for perennial legume-grass pastures than for annual forage crops or perennial grass pastures was the result of the combined effects of lower average forage costs and high cattle productivity.
\end{abstract}

Additional keywords: dryland cropping, tropical forages, tropical pastures.

Received 23 March 2016, accepted 25 August 2016, published online 23 November 2016

\section{Introduction}

Future agricultural production systems will be expected to produce increasing quantities of high quality livestock products to feed the growing global population. This will require a greater proportion of finished beef to be produced from cattle grazing forage (Delgado et al. 2008; Phillips et al. 2011; Hajkowicz and Eady 2015). Achieving this, particularly in tropical environments, will require increased forage quality and longer grazing seasons while ensuring sustainable and profitable systems. In the seasonally dry tropics the growth and nutritive value of pastures is highly variable both within and between years (Mott and Tothill 1984) so that the forage available to cattle usually varies widely in quality and quantity. This creates challenges for beef producers to consistently meet market specifications, which include an ongoing trend towards slaughter of younger, heavier cattle. Thus, development of improved tropical production systems that enable cattle to grow more rapidly and reach specified carcass weights at a younger age will be important for increasing the ability of beef producers to meet market specifications for high value beef and for increasing output, or turnover, of cattle. In turn, both of these aspects have potential to increase the profitability of beef businesses.

A recent collation of the financial performance of beef enterprises across northern Australia (McLean et al. 2014), concluded that many northern beef producers are not generating sufficient profits to fund current and future liabilities. This report confirms previous observations by McCosker et al. (2010) and enterprise analysis conducted in central Queensland (Gowen et al. 2009), which also highlighted the need for northern beef producers to focus on increasing profit. Key contributing factors to low profitability have included an ongoing disconnect between asset values and returns, high debt levels and a declining trend in 'terms of trade'. One consequence of the relationship between asset values and returns is that intensification rather than expansion may often be a more viable option to increase profitability of cattle businesses. Targeted use of high quality forages is one such intensification strategy that has the potential to improve the profitability of beef businesses through increasing enterprise turnover and productivity.

The Fitzroy River catchment in central Queensland is an important beef-producing area of northern Australia producing $\sim 10 \%$ of Australia's total gross value of cattle from $\sim 12.3$ million ha of pastures (ABS 2014a, 2014b). Of the four major land types in the region, three (brigalow, open downs and alluvial) have arable soils capable of supporting grain crops and/or sown forages suitable for finishing beef cattle. Furthermore a substantial proportion of these arable soils in the region is presently used for growing perennial grass pastures and could 
be utilised more intensively (Gillespie et al. 1991; Bourne and Tuck 1993; ABARES 2015).

The objective of the present study was to measure forage, animal and economic performance, and thus determine the key drivers of profitability, for major annual and perennial dryland forage systems used for beef cattle production in the Fitzroy River catchment of Queensland. This region was considered as an example of an important beef-producing area in the tropics. Some aspects of this research have appeared elsewhere (Bowen et al. 2015a, 2015b).

\section{Materials and methods}

All procedures were approved by the Queensland Department of Agriculture and Fisheries' Animal Ethics Committee (Reference number: SA 2011/03/348).

\section{Sites, forages, animals and experimental procedures}

Twenty-one dryland forage sites were studied on 12 commercial beef co-operator properties across the Fitzroy River catchment in central Queensland during the period January 2011-April 2014. The Fitzroy River catchment $\left(21.27-26.43^{\circ} \mathrm{S}, 146.57-\right.$ $151.28^{\circ} \mathrm{E}$ ) is located within the subtropical, semiarid zone of Queensland. The average annual rainfall of $\sim 629$ (s.d. 164.8) mm is characterised by high annual variability (range $274-1117 \mathrm{~mm}$ ) and a strong summer incidence ( $70 \%$ occurs between October and March).

The forages studied were the annual forage crops of oats (Avena sativa), sorghum (Sorghum spp.) and lablab (Lablab purpureus), and sown perennial legume-grass pastures of leucaena-grass (Leucaena leucocephala spp. glabrata + perennial, tropical grass $\left(\mathrm{C}_{4}\right)$ species) and butterfly pea-grass (Clitoria ternatea + perennial, $\mathrm{C}_{4}$, grass species). Perennial, $\mathrm{C}_{4}$, grass pastures were also studied to represent an industry baseline. The locations of the 21 forage sites within the Fitzroy River catchment are shown in Fig. 1. Several sites (paddocks) were studied for more than 1 year and sometimes several sites were located on a single commercial property (Table 1). The number of sites and datasets obtained for each forage type are summarised in Table 2. Annual datasets for forage types ranged from two (lablab) to eight (oats), and reflected the seasonal conditions during the study period as well as the number of producers planting each forage type, and hence the number of potential producer co-operators. One of the five sorghum crops studied (property 11, paddock 1; Table 1) was a ratoon (i.e. regrowth) crop, which had also been monitored in the first season after planting (i.e. the crop was planted once and then grazed and monitored over two seasons). Two of three perennial grass pasture sites were of brigalow land type and consisted primarily of introduced species, primarily buffel (Pennisetum ciliare; property 10, paddock 2; Table 1) but also sabi (Urochloa mosambicensis) and green panic (Panicum maximum var. trichoglume) at one of these sites (property 9 , paddock 3; Table 1). The third site with open downs land type (property 3, paddock 5; Table 1) consisted of approximately equal proportions of introduced (primarily buffel) and native (primarily Queensland bluegrass (Dicanthium sericeum)) pasture species.

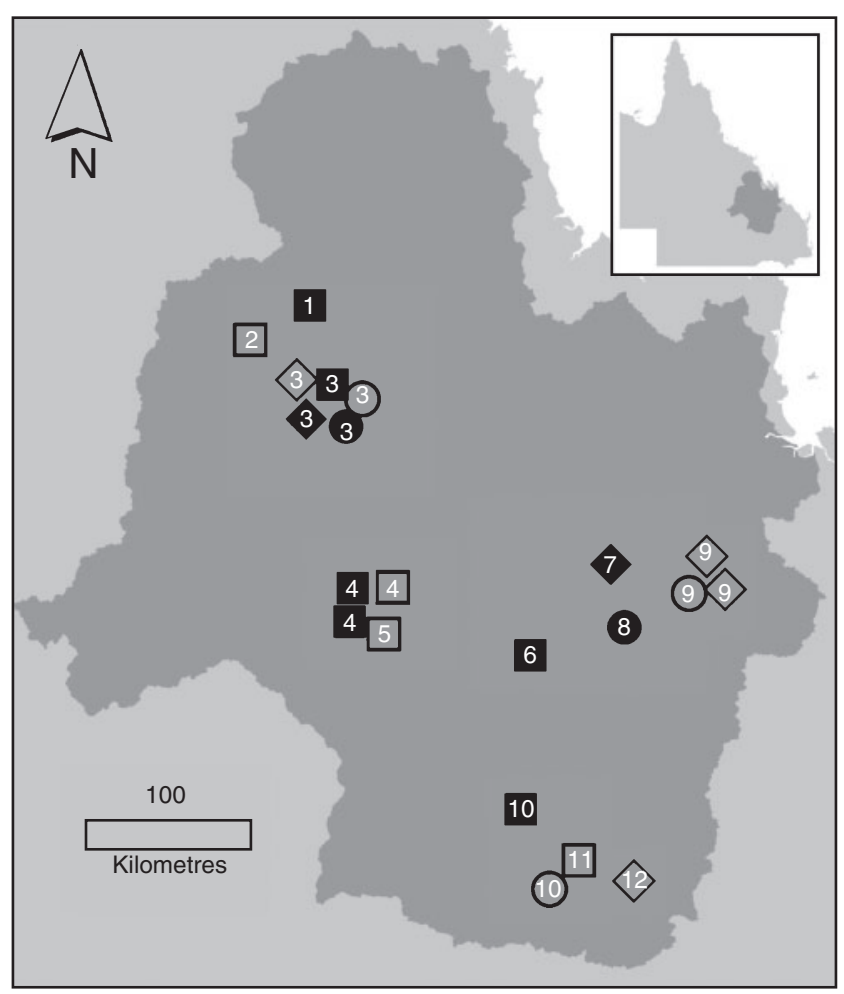

Fig. 1. Map showing the location of forage sites on commercial properties in the Fitzroy River catchment of Queensland for oats (closed square), sorghum (open square), lablab (closed diamond), leucaena-grass (open diamond), butterfly pea-grass (closed circle); perennial grass (open circle). The number within each symbol indicates the commercial property on which the site was located.

The areas of the sown forage within sites (i.e. paddocks) that were used in the study ranged widely in size from 22 to 365 ha (Table 1). These sown forage areas were often only a part of larger paddocks, which also contained areas of perennial grass pasture, typical of the use of these forages in the Fitzroy River catchment, so that the total available grazing area ranged from 44 to 603 ha (Table 1). On average, annual forage crop sites contained perennial grass pasture areas, which comprised $39 \%$ of the total grazing area (Table 3). Perennial legume-grass sites also had substantial areas which had not been sown to legume, comprising on average $23 \%$ and $12 \%$ of the total grazing area for leucaena-grass and butterfly pea-grass sites, respectively. The total grazing area for the three perennial grass sites ranged from 85 to 1023 ha. The annual monitoring period extended from the start of grazing at the forage site to either the end of the grazing period for the annual forages, or to as close as possible to a 365-day period for perennial pasture sites. The annual monitoring periods for perennial forage sites were generally measured for close to 365 days. Exceptions to this were a leucaena-grass site and a perennial grass site, both on the same property (property 9, paddocks 1 and 3), where the monitoring period was 476 days, which included very dry seasonal conditions for 197 days before the final 74 days of grazing.

The beef producer co-operators at each site continued to use their normal management practices in relation to the forages and 
Table 1. Summary of number and type of forage sites located on each of 12 commercial properties in the Fitzroy River catchment, the years of data collection, and the area of sown forage and perennial grass within each site

\begin{tabular}{lclccc}
\hline Property & Site (paddock) & Forage type & $\begin{array}{c}\text { Number of years of data } \\
\text { collection (year/s) }\end{array}$ & $\begin{array}{c}\text { Sown forage } \\
\text { area (ha) }\end{array}$ & $\begin{array}{c}\text { Total grazing } \\
\text { area (ha) }\end{array}$ \\
\hline 1 & 1 & Oats & $1(2011)$ & 22 & 164 \\
2 & 1 & Sorghum & $1(2012-13)$ & 229 & 458 \\
3 & 1 & Oats & $1(2013)$ & 140 & 169 \\
& 2 & Lablab & $2(2012-13,2013-14)$ & 219 & 509 \\
& 3 & Leucaena-grass & $2(2012-13,2013-14)$ & 209 & 262 \\
& 4 & Butterfly pea-grass & $2(2011-12,2012-13)$ & - & 1023 \\
4 & 5 & Perennial grass & $1(2012)$ & 340 & 603 \\
& 1 & Oats & $1(2013)$ & 79 & 223 \\
5 & 2 & Oats & $1(2011-12)$ & 365 & 603 \\
6 & 3 & Sorghum & $1(2012-13)$ & 198 & 246 \\
7 & 1 & Sorghum & $1(2011)$ & 47 & 60 \\
8 & 1 & Oats & $1(2012-13)$ & 64 & 87 \\
9 & 1 & Lablab & $1(2012-13)$ & 28 & 44 \\
& 1 & Butterfly pea-grass & $1(2013-14)$ & 52 & 97 \\
10 & 1 & Leucaena-grass & $1(2012-13)$ & 66 & 85 \\
& 2 & Leucaena-grass & $3(2011,2012,2013)$ & 85 & 125 \\
11 & 3 & Perennial grass & $2(2011-12,2012-13)$ & - & 305 \\
\hline
\end{tabular}

Table 2. Soil and forage characteristics for six forage types grazed by cattle on commercial properties in the Fitzroy River catchment DMD, dry matter digestibility; CP, crude protein; N, nitrogen; P, phosphorus. Results are presented as mean \pm s.e. $n / a=$ not applicable

\begin{tabular}{|c|c|c|c|c|c|c|}
\hline & \multicolumn{3}{|c|}{ Annual forages } & \multicolumn{3}{|c|}{ Perennial forages } \\
\hline & Oats & Sorghum & Lablab & Leucaena-grass & Butterfly pea-grass & Perennial grass \\
\hline Number of datasets (number of sites/paddocks) & $8(6)$ & $5(4)$ & $2(2)$ & $5(4)$ & $3(2)$ & $5(3)$ \\
\hline Soil nitrate- $\mathrm{N}(\mathrm{kg} / \mathrm{ha})^{\mathrm{A}}$ & $86 \pm 23.4$ & $78 \pm 7.6$ & - & - & - & - \\
\hline $\begin{array}{l}\mathrm{N} \text { fertiliser ( } \mathrm{kg} \mathrm{N} / \mathrm{ha} \text { ); } \\
\quad \text { (proportion of crops fertilised) }\end{array}$ & $\begin{array}{l}38 \pm 8.4 \\
(3 / 8)\end{array}$ & $\begin{array}{l}45 \pm 4.5 \\
(2 / 5)\end{array}$ & - & - & - & - \\
\hline Soil P $(\mathrm{mg} / \mathrm{kg})^{\mathrm{B}}$ & $21 \pm 4.3$ & $47 \pm 27.9$ & $19 \pm 4.0$ & $39 \pm 23.7$ & $59 \pm \mathrm{n} / \mathrm{a}$ & $19 \pm 6.2$ \\
\hline Forage peak biomass in ungrazed exclosure (t DM/ha) & $8.2 \pm 1.41$ & $19.3 \pm 5.66$ & $9.6 \pm 4.62$ & - & - & - \\
\hline Forage peak biomass in grazed paddock (t DM/ha) & $4.6 \pm 0.35$ & $12.2 \pm 5.25$ & $6.0 \pm 0.53$ & - & - & - \\
\hline \multirow[t]{2}{*}{ Forage biomass in grazed paddock $(\mathrm{t} \mathrm{DM} / \mathrm{ha})^{\mathrm{C}}$} & - & - & - & $\begin{array}{l}\text { Leucaena: } \\
0.4 \pm 0.98\end{array}$ & $\begin{array}{c}\text { Butterfly pea: } \\
0.5 \pm 0.31\end{array}$ & - \\
\hline & - & - & - & $\begin{array}{c}\text { Grass: } \\
3.8 \pm 0.55\end{array}$ & $\begin{array}{l}\text { Grass: } \\
4.6 \pm 0.60\end{array}$ & $3.7 \pm 0.41$ \\
\hline \multicolumn{7}{|l|}{ Start of grazing } \\
\hline Forage green leaf as $\%$ of biomass ( $\%$ DM) & $61 \pm 5.4$ & $33 \pm 8.4$ & $45 \pm 13.0$ & - & - & - \\
\hline Forage green leaf $\mathrm{CP}(\mathrm{g} / \mathrm{kg} \mathrm{DM})$ & $131 \pm 19.9$ & $133 \pm 6.72$ & $223 \pm 42.5$ & - & - & - \\
\hline Forage green leaf DMD (\%) & $79 \pm 1.0$ & $66 \pm 0.9$ & $75 \pm 2.5$ & - & - & - \\
\hline
\end{tabular}

${ }^{\mathrm{A}}$ Measured at planting but after any fertiliser applications. Measurements made to rooting depth $(90-120 \mathrm{~cm})$.

${ }^{\mathrm{B}}$ Colwell bicarbonate extraction; measured at planting in top $0-10 \mathrm{~cm}$ of soil profile.

${ }^{\mathrm{C}}$ Average over annual monitoring period; values for leucaena biomass represent only the edible material (i.e. leaves and stems $<5 \mathrm{~mm}$ in diameter).

the selection and management of cattle (including grazing management and stocking rates) other than measuring cattle liveweight gain when this was not already occurring. For each site, producer management operations, including associated costs and returns, were documented. These included details of forage planting and maintenance operations, cattle movements and associated liveweight at entry and exit from the site, and any animal treatments or supplements applied.
A weather station (Tinytag Data Logger, Hastings Data Loggers, Park Port Macquarie, Australia) was erected at each site to automatically record rainfall during the monitoring period. Where these units were not available for a site, or failed, the rainfall data from the closest Bureau of Meteorology weather station was used. Soil fertility and plant available water content were evaluated from $\sim 10$ soil cores taken across each site at planting of annual forage crops (but after any 
Table 3. Grazing value and total beef production for six forage types grazed by cattle on commercial properties in the Fitzroy River catchment $\mathrm{AE}$, adult equivalent, calculated as cattle liveweight $(\mathrm{kg})$ to the power of 0.75 , divided by $450 \mathrm{~kg}$ to the power of 0.75 ; DMD, dry matter digestibility; $\mathrm{CP}$, crude protein. Results are presented as mean \pm s.e.

\begin{tabular}{|c|c|c|c|c|c|c|}
\hline & \multicolumn{3}{|c|}{ Annual forages } & \multicolumn{3}{|c|}{ Perennial forages } \\
\hline & Oats & Sorghum & Lablab & Leucaena-grass & Butterfly pea-grass & Perennial grass \\
\hline$\%$ of grazing area planted to forage ${ }^{\mathrm{A}}$ & $59 \pm 8.3$ & $67 \pm 5.3$ & $58 \pm 15.0$ & $77 \pm 8.0$ & $88 \pm 12.0$ & - \\
\hline Total days of grazing per annum & $116 \pm 9.4$ & $107 \pm 14.8$ & $107 \pm 4.0$ & $284 \pm 58.6$ & $181 \pm 24.2$ & $224 \pm 78.8$ \\
\hline$\%$ of $\mathrm{C}_{3}$ forage biomass in the $\operatorname{diet}^{\mathrm{C}, \mathrm{D}}$ & $77 \pm 4.7$ & - & $54 \pm 22.5$ & $51 \pm 4.8$ & $21 \pm 14.9$ & $11 \pm 1.7$ \\
\hline $\operatorname{Diet} \mathrm{CP}(\mathrm{g} / \mathrm{kg} \mathrm{DM})^{\mathrm{D}}$ & $123 \pm 7.2$ & $88 \pm 8.0$ & $115 \pm 15.5$ & $120 \pm 7.2$ & $97 \pm 15.6$ & $66 \pm 3.3$ \\
\hline Diet DMD $(\%)^{\mathrm{D}}$ & $63 \pm 1.3$ & $55 \pm 1.2$ & $59 \pm 0.5$ & $59 \pm 3.8$ & $59 \pm 0.3$ & $55 \pm 1.0$ \\
\hline
\end{tabular}

${ }^{\mathrm{A}}$ The remainder of the area consisted of perennial grass-only and, in some cases, timbered areas and watercourses.

${ }^{\mathrm{B}}$ Total grazing area includes both sown high quality forage and associated perennial grass areas present in the paddock. The stocking rate for annuals was expressed as the average over the grazing period. The stocking rate for perennials was the average over each 365-day period of monitoring.

${ }^{\mathrm{C}}$ This is an indication of the proportion of the diet that was sown $\mathrm{C}_{3}$ species (oats and the sown legume species), although any consumption of naturalised legumes and weeds in the grass component of the pasture would be included in this measurement.

${ }^{\mathrm{D}}$ Determined from analysis of faeces. Values represent the average over the entire grazing period.

fertiliser application), and at commencement of monitoring for perennial sites, using a hydraulic soil sampling rig, to a maximum depth of $120 \mathrm{~cm}$. The soil cores were bulked and subsamples taken for analysis for phosphorus (P; Colwell bicarbonate extraction) in the top $0-10 \mathrm{~cm}$ of soil (all forage types) and soil nitrate-nitrogen $(\mathrm{N})$ to rooting depth (oats and sorghum crops), and for determination of plantavailable soil water content to rooting depth (annual forage crops). Soil water content at the end of the grazing period was determined for annual forage crops in the same way as at planting.

The forage biomass (presentation yield) was assessed in the grazed paddock a minimum of two, but usually 4-13 times (depending on length of grazing period) during the monitoring period. Biomass of annual forage crops was assessed by cutting $10-20$ (depending on paddock size and heterogeneity) $0.25-\mathrm{m}^{2}$ quadrats. Biomass of butterfly pea-grass and perennial grass sites, and in the perennial grass portion of the leucaena-grass sites (including any grass-only areas), was assessed on a minimum of 40 quadrats using the BOTANAL procedure (Tothill et al. 1992). The edible biomass of leucaena forage was assessed by hand-stripping all leucaena leaf and small stems $<5 \mathrm{~mm}$ in diameter in a 2-m section of a row in each of four areas considered to be representative of the site. Annual forage crop and edible leucaena biomass was reported per ha of area planted to forage rather than per the total grazing area, which generally included some perennial grass-only areas. Just before the start of the grazing interval for annual forage crops, a representative subsample from the cut quadrats was sorted to determine the proportion of green leaf DM in the pasture. On each occasion, a subsample of green leaf was kept for determination of crude protein (CP) and dry matter digestibility (DMD) content. Additionally, a subsample of edible leucaena was kept at each biomass sampling for determination of CP and DMD. After planting, fenced exclosure sites $(9 \mathrm{~m} \times$ $9 \mathrm{~m}$ ) were established at all annual forage crop sites to exclude cattle. On each occasion that biomass was assessed in the grazed paddock, the biomass was also assessed from four randomly selected quadrats in the exclosure.
Reflecting typical forage and cattle management in the Fitzroy River catchment, the majority of forage sites had more than one group of cattle (and some up to five groups) graze the paddock sequentially during the annual measurement period, with cattle often progressively withdrawn as they reached target weights and then new groups added. The cattle selected by producers to graze in trial paddocks were primarily steers, although occasionally heifer groups were used. Entry liveweight of cattle ranged from $197 \mathrm{~kg}$ (6-11-month-old heifers grazing perennial grass pasture) to $622 \mathrm{~kg}$ (2.5-yearold steers grazing oats). All cattle contained a proportion of Bos indicus content, ranging from $13 \%$ to $100 \%$ across groups. Individual cattle liveweight was recorded a minimum of twice, at entry and exit of cattle from the forage site, but usually additional intermediate liveweight measurements were obtained. Every 4-6 weeks during the grazing period faecal samples were collected in the paddock from a minimum of 10 , but preferably 20 , fresh dung pats from individual cattle for analysis by near-infrared reflectance spectroscopy, and mass spectroscopy for $\delta^{13} \mathrm{C}$ except at forage sorghum sites.

\section{Analytical procedures}

Soil samples were dried at $40^{\circ} \mathrm{C}$ to constant weight before analysis for nitrate- $\mathrm{N}$ and $\mathrm{P}$ (Colwell bicarbonate extraction) in a commercial laboratory (Incitec, Melbourne, Vic., Australia) using techniques described by Rayment and Lyons (2011). Soil water content was determined by oven drying soil samples at $105^{\circ} \mathrm{C}$ until constant weight. The plant-available soil water content was determined by calculating volumetric soil water content, accounting for soil bulk density, and subtracting the amount of water left in the soil at the end of the grazing period, with adjustment for rainfall (i.e. the crop lower limit). DM content of forage samples was determined by drying to a constant weight in a forced draught oven at $65^{\circ} \mathrm{C}$. Forage samples were milled to $<1 \mathrm{~mm}$ before analysis for total $\mathrm{N}$ concentration by a combustion method (Sweeney 1989) with an Elementar Rapid-N combustion analyser (Elementar Analysensysteme GmbH, Hanau, Germany). Forage 
and faecal samples were milled to $<1 \mathrm{~mm}$ with a Model 1093 Cyclotec mill (Foss Tecator AB, Hoganas, Sweden), oven-dried (forage samples redried at $60^{\circ} \mathrm{C}$ for $18 \mathrm{~h}$; faecal samples at $65^{\circ} \mathrm{C}$ to constant weight) and then scanned in spinning cups using a Foss 6500 near-infrared spectrometer (Foss NIRSystems Inc., Laurel, MD, USA). The DMD of the forage components on offer, and the DMD and total $\mathrm{N}$ concentration of the diet selected by the cattle were predicted using forage and faecal near-infrared spectrometer calibrations suitable for these pasture systems (Coates 2004; Dixon and Coates 2009; Coates and Dixon 2011). Dried and milled faecal samples were further ball-milled to fine powder before determination of $\delta^{13} \mathrm{C}$, using a continuous flow system consisting of a Delta V Plus mass spectrometer connected with a Thermo Flush 1112 via Conflo IV (Thermo-Finnigan, Germany). The proportion of the diet comprising $\mathrm{C}_{3}$ forages (i.e. forage oats, legumes and any dicot forbs or browse) was calculated allowing for diet-tissue discrimination of $-1 \%$ units (where \%o denotes one part per thousand) and accounting for the average measured difference in digestibility between $\mathrm{C}_{3}$ and $\mathrm{C}_{4}$ species for each forage system (Jones et al. 1979; Norman et al. 2009). A representative crosssection of forage samples from all forage types were analysed for $\delta^{13} \mathrm{C}$ using the same procedures as that for faecal samples to determine the $\delta^{13} \mathrm{C}$ typical of the forage species in our study. The average $\delta^{13} \mathrm{C}$ for $\mathrm{C}_{3}$ forage species was oats -28.1 $\pm 0.38 \%$ o $(n=12)$, lablab $-30.1 \pm 0.60 \%$ o $(n=5)$, butterfly pea $-31.0 \pm 0.42 \%$ o $(n=4)$ and leucaena $-28.3 \pm 0.38 \%$ o $(n=13)$; and $-14.4 \pm 0.10 \%$ o $(n=26)$ for $\mathrm{C}_{4}$ species, which included introduced and native perennial grass species (buffel, sabi, green panic, rhodes (Chloris gayana), bambatsi panic ( $P$. coloratum), Indian bluegrass (Bothriochloa pertusa), Queensland bluegrass, and forest bluegrass (B. bladhii)).

\section{Economic analyses}

To facilitate communication with, and extension messages to, beef producers and the wider beef industry, gross margins adjusted for differences in forage establishment costs were used to measure economic performance rather than a net present value. Gross margins were calculated for each forage dataset based on the forage and cattle management at each site and on actual costs and returns, where possible. Where prices were unavailable from producers, they were estimated based on current regional prices at the time of the transactions. Gross margins were calculated as the gross income from the sale of cattle less the variable costs incurred, including both livestock purchase and treatment costs and costs of producing the forage, which included labour (costed at $\$ 25 / \mathrm{h}$ ) and other variable costs of machinery operations.

Gross margins received from annual forage crops were compared with the gross margins of the perennial legumegrass forage systems by including the establishment costs of the latter as an average annual (amortised) cost over the expected life of the forage. The amortisation process included the opportunity cost of the capital applied in the pasture establishment process (assumed interest rate of 5\%, taken as the real opportunity cost of funds to the producer) plus an allowance for the value of any grazing foregone during the establishment period of the perennial forage. The expected life of each perennial legume-grass forage site was assigned based on the individual condition and management of forage at each site: 10 years for the butterfly pea-grass sites, 20 years for three of the four leucaena-grass datasets and 30 years for the fourth.

Cattle were valued in and out of the forage site regardless of whether they were already owned by the producer, or were retained on the property after grazing finished at the forage site. The livestock value into the site, for cattle purchased immediately before grazing the forage, was calculated as the landed purchase cost, including transport and buying costs. The value of cattle already owned by the business was calculated as the current market price less all the expenses that would be required to sell the stock and realise that value. Thus, total livestock costs included purchase cost, animal health expenses, sale levies, freight and the opportunity cost of livestock capital. Labour costs of handling the livestock were excluded on the basis that such livestock costs are unlikely to differ appreciably between forage types on an annual basis. The opportunity cost involved in owning the cattle was accounted for by calculating the amount of interest that could have been received on the livestock capital if the forage enterprise had not been undertaken and subtracting this amount from the gross margin. An assumed interest rate of $5 \%$ was used, reflecting the opportunity cost of capital to beef businesses during the years 2011-2014.

Gross margins were calculated using two methods for each forage dataset. The first method incorporated a best estimate of the regional contract rate to cost the machinery operations used by the producer (contract rates). For this method, overhead, operating and labour costs were apportioned on a per-hectare basis for the use of the machines or combinations of machines. Additionally, a nominal allowance for contractor profit of $20 \%$ of the total combined machinery operating costs per ha, and minor travel costs, was added. Overhead costs included an allowance for the capital invested in the machinery as well as depreciation. For the second method, machinery operations were costed as if plant and machinery were owned by the business, but with overhead costs excluded (owner rates). In this method, labour associated with machinery operations were costed, even if the labour was unpaid, to account for differences in time required to grow the various forages. The large number of forage species, sites, and groups of cattle within sites, as well as the use of actual data in the calculations made comprehensive sensitivity analysis impractical. Nevertheless, the relative impact of variation in the key drivers of profitability was tested in several datasets.

\section{Statistical analyses}

The objective was to measure forage production and profitability under commercial conditions across the Fitzroy River catchment study area. Each site contained only a single forage type and was characterised by its own combination of management decisions, seasonal influences and market prices. Therefore, forage types were not replicated and were confounded with sites so that statistical treatment of the data was necessarily limited. Forage type summaries consisted of means, and within forage type variation expressed as standard errors, allowing basic comparisons among forage types. Relationships between 
the major explanatory variables (total beef production, forage costs and cattle price margin) and forage gross margin were investigated through multiple linear regression.

\section{Results}

The quantitative values and variability within each pasture system are of primary interest but overall relationships between forage, animal and financial data are discussed. General conclusions have been drawn where appropriate.

\section{Rainfall and soil fertility}

Total rainfall measured during the monitoring period showed high variability between datasets for each forage type (Fig. 2). For annual forage crops, the sum of plant-available soil water at planting and in-crop rainfall was lower for oats crops (312 mm) than for the summer forages sorghum and lablab (456 and $540 \mathrm{~mm}$, respectively). Average rainfall measured over the annual monitoring period for the perennial forages was higher than the annual average of $629 \mathrm{~mm}$ (climate normal mean, representing the average rainfall over the 30 -year period from 1961 to 1990; BOM 2014) for the Fitzroy River catchment (leucaena-grass, 667, butterfly pea-grass, 631 and perennial grass, $663 \mathrm{~mm}$ ). However, 7/13 perennial forage datasets had annual rainfall totals $<629 \mathrm{~mm}$. Very high pre-crop and in-crop rainfall was associated with very high yielding forage crops (e.g. $184 \%$ of the mean for one of the sorghum crops and $201 \%$ for one of the oats crops). Soil nitrate-N concentrations for annual cereal crops (measured after any $\mathrm{N}$ fertiliser application), ranged from 42 to $134 \mathrm{~kg} / \mathrm{ha}$ for individual datasets, with an average of 86 and $78 \mathrm{~kg} / \mathrm{ha}$ across oats and sorghum datasets, respectively (Table 2). Only some of the oats $(3 / 8)$ and sorghum $(2 / 5)$ crops received $\mathrm{N}$ fertiliser at average applications of 38 and $45 \mathrm{~kg} \mathrm{~N} /$ ha, respectively. Soil P levels in the top $10 \mathrm{~cm}$ of soil ranged from 7 to $130 \mathrm{mg} / \mathrm{kg}$ across all forage

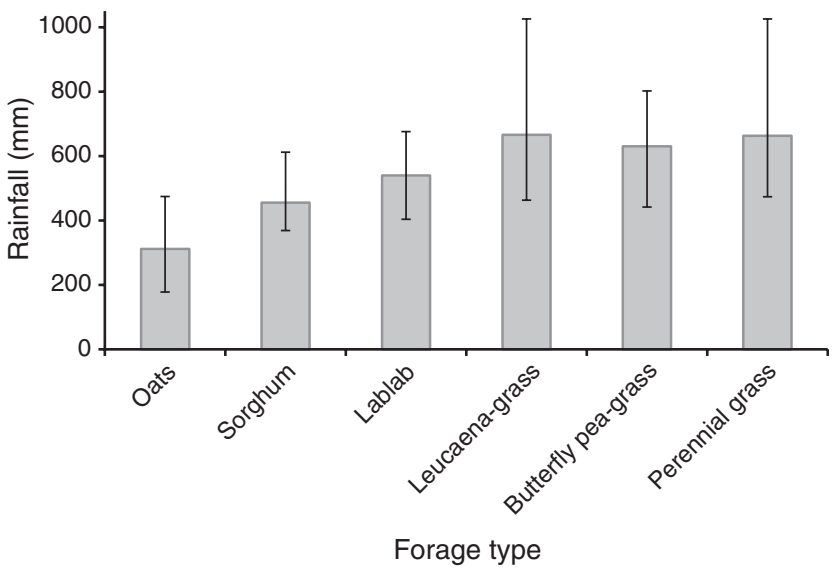

Fig. 2. Rainfall during the monitoring period for six forage types grazed by cattle on commercial properties in the Fitzroy River catchment. The rainfall for annual forage crops (oats, sorghum and lablab) is the sum of the plant available soil water at planting and in-crop rainfall (i.e. rainfall from planting until end of the grazing period). The rainfall for perennial forages (leucaenagrass, butterfly pea-grass and perennial grass) is the total during the annual monitoring period. Data are the mean value across forage datasets within forage type. Error bars show the range of values. datasets. Whereas the average $\mathrm{P}$ concentration across all datasets was $31 \mathrm{mg} / \mathrm{kg}, 10 / 20$ datasets with available data for $\mathrm{P}$ had concentrations $<20 \mathrm{mg} / \mathrm{kg}$ and $3 / 20$ datasets had $\leq 11 \mathrm{mg} / \mathrm{kg}$. Furthermore, 2/4 leucaena-grass sites had $\mathrm{P}$ concentrations $<20 \mathrm{mg} / \mathrm{kg}$ (11 and $15 \mathrm{mg} / \mathrm{kg})$.

\section{Forage biomass and composition}

The maximum forage biomass measured during the monitoring period (hereafter, peak biomass) in the exclosure sites of annual crops was similar for oats and lablab (8.2 and 9.6 t DM/ha), respectively, whereas peak biomass for sorghum crops was 19.3 t DM/ha (Table 2). A similar trend was observed for peak biomass of forage in the grazed crop paddocks, with sorghum (12.2 $\mathrm{t} \mathrm{DM} / \mathrm{ha}) \sim$ double that for lablab $(6.0 \mathrm{t} \mathrm{DM} / \mathrm{ha})$ and 2.7 times that for oats $(4.6 \mathrm{t} \mathrm{DM} / \mathrm{ha})$. Measurements over the annual monitoring periods for the perennial forages showed that the biomass of the legume component (whole plant for butterfly pea but the edible component, only, of leucaena) to be only $\sim 10 \%$ of the grass component of the pasture $(0.5$ and $0.4 \mathrm{t} \mathrm{DM} / \mathrm{ha}$ for butterfly pea and edible leucaena, respectively, cf. 4.6 and $3.8 \mathrm{t} \mathrm{DM} /$ ha for the grass components). Grass biomass for the perennial grass pastures $(3.7 \mathrm{t} \mathrm{DM} / \mathrm{ha})$ was similar to that measured for legume-grass pastures. The percentage of annual forage crop biomass that was green leaf at the start of the grazing period was $61 \%$ DM for oats whereas it was only $33 \%$ and $45 \% \mathrm{DM}$ for sorghum and lablab crops, respectively. The average CP content of green leaf at the start of grazing was similar for oats and sorghum (131 and $133 \mathrm{~g} / \mathrm{kg} \mathrm{DM}$; Table 2) but there was a large range of values across individual cereal crop datasets (45-214 g/ $\mathrm{kg} \mathrm{DM})$. The green leaf CP at start of grazing for lablab $(220 \mathrm{~g} / \mathrm{kg}$ DM) was much greater than for cereal crops. The corresponding DMD of annual forage crop green leaf at the start of grazing was lowest for sorghum: $66 \%$ cf. $79 \%$ for oats and $75 \%$ for lablab. The edible component of leucaena, averaged through the annual cycle, was high in $\mathrm{CP}$ (230 g/kg DM) but only 64\% DMD (data not presented).

\section{Diet quality and cattle production}

The percentage of $\mathrm{C}_{3}$ species in the diet of cattle, ranked from highest to lowest, was: oats, 77; lablab, 54; leucaena-grass, 51; butterfly pea-grass, 21; and perennial grass, $11 \%$ (Table 3 ). The small $\mathrm{C}_{3}$ component in the perennial grass pasture represents the presence of naturalised legumes (native and introduced), and other dicots, in the pasture. The diet CP and DMD of grazing cattle, measured by faecal near-infrared reflectance spectroscopy, were highest for those grazing oats $(123 \mathrm{~g} / \mathrm{kg}$ DM and 93\%, respectively; Table 3). The tropical legume forages also resulted in high quality diets: leucaena-grass (120 and 59), lablab (115 and 59), and butterfly pea-grass (97 g CP/kg DM and 59\% DMD, respectively). Diet CP was greater from sorghum crops than from perennial grass pastures (88 vs $66 \mathrm{~g} / \mathrm{kg} \mathrm{DM}$ ), but cattle had similar DMD (average 55\%).

The average stocking rate over the total grazing area was 1.7 adult equivalent (AE)/ha for sorghum crops and 1.0 AE/ha for oats and lablab (Table 3). The total days of grazing averaged 116 for oats crops and 107 for the summer forages, sorghum and lablab (Table 3). Stocking rates over the total grazing area for perennial forages, expressed per annum, were considerably 
less than for the annual forage crops (leucaena-grass, 0.76; butterfly pea-grass, 0.58; and perennial grass, $0.37 \mathrm{AE} / \mathrm{ha}$ ) and corresponding days of grazing per annum considerably more (leucaena-grass, 284; butterfly pea-grass, 181; and perennial grass, 224 days).

Annual cattle liveweight gain per ha varied greatly both among and within forage types (Table 3). Total liveweight gain over the total grazing area was greatest for leucaena-grass and least for perennial grass pastures (leucaena-grass, 198; butterfly pea-grass, 125; sorghum, 108; lablab, 99; oats, 93; and perennial grass, $76 \mathrm{~kg} / \mathrm{ha}$.annum). Sown forages resulted in 1.2-2.6 times the annual liveweight gain per ha than perennial grass pastures. There was less variability in total liveweight gain among datasets for leucaena-grass pasture (coefficient of variation (CV) 36\%) than for perennial grass (CV 97\%) and butterfly pea-grass (CV 84\%) pastures.

\section{Economic analyses}

Contract rates for annual forage costs per area sown were considerably greater for annual forage crops (range \$142-194/ ha.annum) than for perennial legume-grass forages (\$26-39/ha. annum, amortised value); (Table 4). One of the three perennial grass sites incurred costs of regular blade ploughing (every 20 years) to control brigalow (Acacia harpophylla) regrowth, which resulted in an average forage cost for all of the perennial grass datasets of $\$ 3 / \mathrm{ha}$. Using owner rates to calculate forage costs resulted in figures that were $69 \%$ of contract rates for the annual forage crops, and $84 \%$ of contract rates for the perennial legume-grass forages. Gross margins calculated using contract rates and expressed per total grazing area were greatest for leucaena-grass forage, \$181/ha.annum (Table 4). The other perennial legume-grass forage studied, butterfly pea-grass, produced the second highest gross margin, \$140/ha.annum. Although oats forage produced a similar gross margin to perennial grass pasture (\$102 cf. 96/ha.annum), forage sorghum and lablab resulted in lower gross margins than for perennial grass (\$24 and \$18/ha.annum, respectively). Gross margins calculated using owner rates were greater but resulted in the same ranking of forages. The regional prices for both store cattle (i.e. entry values) and finished cattle (i.e. exit values) showed high variability during the period of data collection (Fig. 3). This resulted in a large range in cattle price margin (sale price less purchase price, $\$ / \mathrm{kg}$ liveweight) across all 28 datasets: $-\$ 0.40$ to $0.45 / \mathrm{kg}$ liveweight; average $\$ 0.07 / \mathrm{kg}$ liveweight). Sensitivity analysis indicated that a $10 \%$ improvement in cattle sale price had a much greater effect on gross margin than a $10 \%$ improvement in cattle liveweight gain or a $10 \%$ reduction in forage costs for annual forages. Changes in cattle sale price resulted in up to five times the effect of changes in cattle liveweight gain and up to 10 times the effect of changes in forage costs. A $10 \%$ change in forage costs had a much larger effect on gross margin for annual forages than for perennial forages due to the higher growing costs associated with annual forages. A significant relationship between the three explanatory variables, of total liveweight gain, forage costs and cattle price margin, and gross margin was observed $\left(R^{2}=0.38, P<0.01\right)$. Total liveweight gain and cattle price margin had a positive effect on gross margin whereas forage costs had a negative effect.

\section{Discussion}

The data reported here for forage, animal and economic performance for grazed, dryland forage production systems in the Fitzroy River catchment of northern Australia have strong industry relevance and application due to being measured under commercial management conditions. The results must be interpreted in the context of the individual management decisions, prevailing weather and market factors at each site which contributed to high within-forage type variability. In addition, it must be recognised that gross margins are only the first step in determining the effect of sown forages on farm profitability and may not represent the final impact on business profit of growing the forages. Despite these limitations, the data indicate that perennial legume-grass pastures, and particularly leucaena-grass pastures, result in greater profitability on average, as indicated by gross margins, than annual forage crops or perennial grass pastures. Relatively low forage costs (compared with

Table 4. Forage growing costs and gross margins, calculated using both owner rates and contract rates, for six forage types grazed by cattle on commercial properties in the Fitzroy River catchment

Results are presented as mean \pm s.e.

\begin{tabular}{|c|c|c|c|c|c|c|}
\hline & \multicolumn{3}{|c|}{ Annual forages } & \multicolumn{3}{|c|}{ Perennial forages } \\
\hline & Oats & Sorghum & Lablab & Leucaena-grass & Butterfly pea-grass & Perennial grass \\
\hline \multicolumn{7}{|c|}{ Forage costs per sown area $(\$ / \text { ha.annum })^{\mathrm{A}}$} \\
\hline Contract rates ${ }^{\mathrm{C}}$ & $194 \pm 24.1$ & $142 \pm 46.5$ & $144 \pm 16.5$ & $39 \pm 6.0$ & $26 \pm 2.7$ & $3 \pm 2.0$ \\
\hline Owner rates ${ }^{\mathrm{D}}$ & $136 \pm 14.4$ & $96 \pm 31.7$ & $99 \pm 14.0$ & $34 \pm 4.8$ & $21 \pm 0.0$ & $2 \pm 1.2$ \\
\hline \multicolumn{7}{|c|}{ Gross margin per total grazing area $(\$ / \text { ha.annum })^{\mathrm{B}}$} \\
\hline Contract rates ${ }^{\mathrm{C}}$ & $102 \pm 19.6$ & $24 \pm 47.7$ & $18 \pm 2.5$ & $181 \pm 35.3$ & $140 \pm 118.6$ & $96 \pm 51.7$ \\
\hline Owner rates ${ }^{\mathrm{D}}$ & $131 \pm 17.3$ & $54 \pm 49.5$ & $44 \pm 6.0$ & $184 \pm 35.5$ & $143 \pm 117.9$ & $98 \pm 52.1$ \\
\hline
\end{tabular}

${ }^{\mathrm{A}}$ Forage costs were the costs of forage establishment and maintenance. For butterfly pea-grass and leucaena-grass pastures that have a productive life of more than 1 year, the establishment costs were amortised (expressed as an average annual cost over the expected life of the forage).

${ }^{\mathrm{B}}$ Gross margins were calculated as the gross income received from the sale of cattle less the variable costs incurred, and were expressed after subtracting interest on livestock capital.

${ }^{\mathrm{C}}$ Calculated using a contract rate to cost actual machinery operations used by the co-operator.

${ }^{\mathrm{D}}$ Calculated as if plant and machinery was owned by the business. 


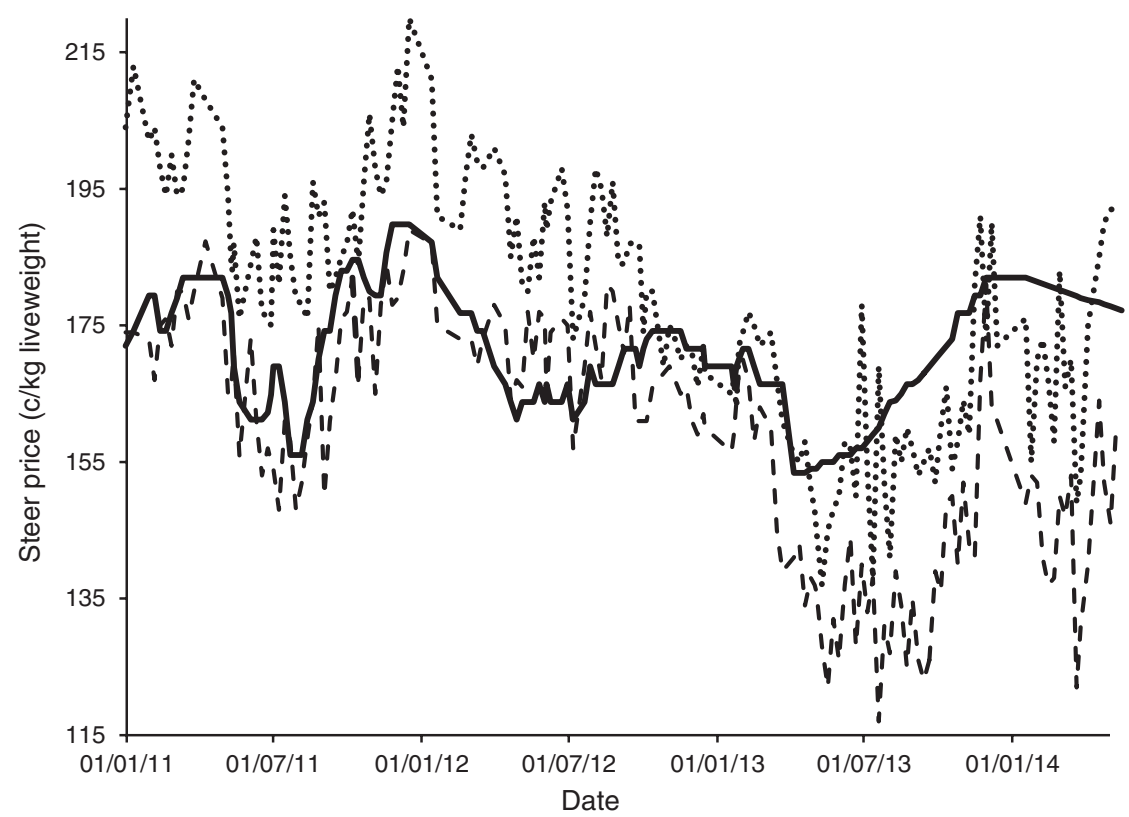

Fig. 3. Cattle market prices for the region over the period of data collection from producer co-operator sites: store steers at Roma (351-400 kg liveweight; dotted line) and Gracemere (401-500 kg liveweight; dashed line) saleyards and grass-fed ox at Dinmore abattoir (300-319 kg dressed weight; solid line). Steer price per dressed weight at Dinmore was converted to liveweight equivalent assuming $52 \%$ dressing.

annual forage crops), combined with high productivity, appear to be the primary factors.

The ranking of leucaena-grass and butterfly pea-grass forages as first and second, respectively, in terms of gross margin is consistent with their ranking in terms of annual beef production per ha, and also with their ranking in terms of forage costs for sown forages, which was in the reverse order. These results were seen despite the relatively small proportion of edible legume in the total pasture biomass $(\sim 10 \%)$, which nevertheless resulted in legumes forming, on average, $51 \%$ and $21 \%$ of the diet for cattle grazing leucaenagrass and butterfly pea-grass pastures, respectively. The forage and cattle production from leucaena-grass and butterfly peagrass pastures in this study were comparable with values reported by others, as was the increase in beef production relative to perennial grass pastures (Clem 2004; Shelton and Dalzell 2007; Hill et al. 2009). The ranking of leucaena-grass pastures as the most profitable forage in this study is consistent with the relatively high levels of industry adoption of this legume compared with other pasture legumes (Peck et al. 2011). The area currently planted to leucaena is estimated to be 150000-250000 ha for Queensland (Shelton and Dalzell 2007; The Leucaena Network, pers. comm.), which includes $\sim 105000$ ha for the Fitzroy natural resource management region (T. Beutel, pers. comm.). Peck et al. (2011) estimated that only $3 \%$ of the area adapted to leucaena in Queensland has been currently planted, indicating further significant potential for beef producers to improve productivity and profitability. Given that half of all leucaena-grass sites (as well as half of the total forage dataset), with available data for $\mathrm{P}$, had concentrations less than the recommended level of $20 \mathrm{mg} / \mathrm{kg}$ for leucaena (Peck et al. 2015) there is also potential for additional productivity gains with the appropriate use of $\mathrm{P}$ fertiliser.

The capacity of legumes and particularly leucaena, relative to grass-only pastures, to improve productivity and returns in the tropics are widely accepted (Myers and Robbins 1991; DPI\&F 2005; Donaghy et al. 2010; Peck et al. 2011, 2012). However, the profitability of legume-grass pastures relative to annual forage crops has not been documented. The relatively lower profitability of annual forage crops observed in the present study, particularly when contract rates were used, is in contrast to results of enterprise-scale bio-economic modelling, which indicated potentially large economic benefits from utilising small areas of irrigated annual forages as part of beef production systems in central Queensland and in northern Australia in general (Bell et al. 2014; Hunt et al. 2014). In the present study, use of contract rates, cf. owner rates, to calculate costs and gross margins had a larger adverse effect on the profitability of annual forage crops than on the perennial legume-grass pastures, due to the requirement for annual replanting of the former group. Including more of the indirect costs of machinery ownership in the gross margin calculation, as when contract rates are used, is likely to more accurately reflect the long-term profitability of forages than gross margins that only include the variable costs (i.e. using owner rates). The lower profitability in this study of annual forage crops relative to perennial legumegrass forages are in accord with the results of economic case studies conducted with five beef producers in central Queensland, which indicated that annual forages were unlikely to make a positive contribution to business profit when the 
alternatives were appropriately considered (Bowen et al. 2015a)

The cattle price margin varied widely across forage datasets in this study. When cattle price margin was held constant across sown forage types, in constructed or modelled scenarios, the tendency towards higher gross margins for perennial legume-grass forages compared with annual forages was corroborated (Bowen et al. 2015a). The price risk associated with the relatively short periods of ownership of many more larger and older steers grazing annual forages tends to make the use of annual forage crops more risky than the use of perennial pastures. This is particularly the case for forage sorghum, which produces a large biomass and thus requires a relatively high stocking rate. Furthermore, there is additional risk associated with obtaining sufficient rainfall to allow planting of annual forage crops in any one year. However, the high initial investment costs required for establishing the legume-grass pastures, and especially leucaena-grass pastures, requires consideration as does the lag time after planting before cash flow becomes positive (e.g. 3-7 years for leucaena-grass systems; Bowen et al. 2010).

When assessing the profitability of forage options, an important consideration is the proportion of years in which conditions may be unsuitable for planting an annual forage crop. Rainfall in the Fitzroy River catchment of Queensland, as for much of the grazing area of northern Australia, is inherently highly variable. It is necessary to extrapolate data measured over short time periods into the longer term climatic context to reflect the full range of seasonal conditions likely to be encountered. Computer simulation models such as APSIM (The Agricultural Production Systems Simulator; McCown et al. 1996; Keating et al. 2003) have potential to facilitate this. For example, using 108 years of historical climate data, the APSIM model predicted that suitable conditions for planting an oats crop occurred in only $67 \%$ of years at Taroom and Banana, and $62 \%$ of years at Capella (Bowen et al. 2010). Data from the present study was used to test the outputs from annual forage and perennial grass biomass models within APSIM, and indicated that the predictions by this model were not accurate for annual forages, particularly for grazed systems (Bowen et al. 2015b). Additionally, the available animal production models are generally poor at predicting performance of grazing cattle in the tropics, primarily due to difficulties in accurately predicting intake of forage (McLennan and Poppi 2005; Dove et al. 2010; McLennan 2014; Bowen et al. 2015b). Further work to improve and validate plant and animal growth models for northern production systems is required before they can be used reliably.

Forage biomass yields for all three species of annual forage crop in the present study were generally at the upper end of the expected range for dryland crops in southern Queensland (Chataway et al. 2011a, 2011b; Bell et al. 2012). The yields were similar to those reported for irrigated crops grown near Trangie, New South Wales (Muldoon 1985, 1986). This may reflect the high pre-crop and in-crop rainfall totals for some of the annual forage crops monitored in our study. The CP content of annual forage cereal crop green leaf at the start of grazing reflected the generally low soil nitrate- $\mathrm{N}$ concentrations and low levels of $\mathrm{N}$ fertiliser application under the commercial management regimes examined, and this would have also influenced the resulting $\mathrm{CP}$ in the diet of grazing cattle. Additionally, diet $\mathrm{CP}$ and DMD for cattle grazing annual forages was lower than that expected if cattle had grazed paddocks sown entirely to forage and thus consumed a diet consisting of $100 \%$ annual forage crop. The substantial areas of perennial grass commonly provided in annual forage crop paddocks also resulted in lower stocking rates when calculated for the entire paddock, and longer total days of grazing, than would be expected for paddocks without any perennial grass areas (Bowen et al. 2015a). Forage sorghum, despite producing twice as much forage biomass as the other annual forages (oats and lablab) resulted in similar annual beef production per ha. This was associated with poor utilisation of the forage sorghum biomass for many crops (i.e. large residual biomass at end of grazing) as well as a lower quality diet and lower individual liveweight gain. Poorly utilised and low quality forage sorghum crops reflect the difficulties commonly experienced under commercial management conditions in managing forage sorghum to maximise the time crops are maintained in the higher quality vegetative state (Bowen et al. 2015a).

The perennial grass sites monitored in this study were considered to be representative of commercial beef cattle grazing enterprises more generally in the Fitzroy River catchment of Queensland. Stocking rates at these sites tended to be greater than what is recommended as long-term sustainable levels (Bowen et al. 2015a). These data support more widespread industry observations and monitoring of stocking rates and land condition (Tothill and Gillies 1992; Beutel et al. 2014; McLean et al. 2014), and may be a response to financial pressures on commercial beef producers (McLean et al. 2014). In our study, the high average stocking rates were in line with the greater than expected beef production ( $\mathrm{kg} / \mathrm{ha}$.annum) and gross margins from perennial grass sites, compared with that expected using more conservative stocking rates (Bowen et al. 2015a).

In this study profitability, expressed as gross margin, was the combined result of beef production, forage costs, and cattle price margin. These factors were, in turn, influenced by management, seasonal and market factors. However, there was no one overriding factor that could be identified as determining the profitability of forages. This highlights the importance of optimising all contributing factors in order to maximise profitability of sown forage systems.

In conclusion, this study provided data for forage, animal and economic performance for a range of forage options for dryland beef production in a region of northern Australia with arable soils, and which represents commercial beef cattle enterprises and typical management practices. The data must be interpreted in the context of the individual management decisions, prevailing weather and market factors at each site. Despite these limitations, the data indicated that perennial legume-grass pastures, and particularly leucaena-grass, resulted in greater profitability than annual forage crops or perennial grass pastures. Relatively low forage costs (compared with annual forage crops), combined with high productivity, appear to be the primary factors. Annual forage crops resulted in gross margins, which were less than (sorghum and lablab), or similar to (oats), those from perennial grass pastures, particularly when contract rates, which incorporate more of the indirect costs involved in growing forages, were used. 


\section{Acknowledgements}

This study was co-funded by the Department of Agriculture and Fisheries, Queensland and Meat and Livestock Australia. We especially acknowledge the valuable contributions and input provided by the many beef producers across the Fitzroy River catchment who allowed collection of data from their forage paddocks. We thank Tim Emery, Byrony Daniels, Cindy McCartney and Debra Corbet for skilled technical support and Terry Beutel for preparing the map showing forage site locations. Sincere thanks, also, to Rob Dixon, David Coates and Peter Isherwood for assisting with forage and faecal NIRS analysis and interpretation. We have also benefited from David Reid's advice in improving the manuscript.

\section{References}

ABARES (Australian Bureau of Agricultural Resources and Economics and Sciences) (2015) Catchment scale land use summary - Fitzroy NRM Region - Queensland. September 2015. (Australian Bureau of Agricultural and Resource Economics and Sciences: Canberra) Available at http://data.daff.gov.au/data/warehouse/9aal/2015/cslusd/Pages/Qld_ Fitzroy.html [Verified October 2016]

ABS (Australian Bureau of Statistics) (2014a) 7121.0 Agricultural Commodities, Australia, 2012-2013. Available at http://www.abs.gov. au/AUSSTATS/abs@.nsf/ProductsbyTopic/97B95C93A7FD9B75CA 2573FE00162CAF?OpenDocument [Verified September 2015]

ABS (Australian Bureau of Statistics) (2014b) 7503.0 Value of Agricultural Commodities Produced, Australia, 2012-13. Available at http://www. abs.gov.au/AUSSTATS/abs@.nsf/DetailsPage/7503.02012-13?Open Document [Verified September 2015]

Bell LW, Lawrence J, Johnson B, Whitbread A (2012) Exploring short-term ley legumes in subtropical grain systems: production, water-use, wateruse efficiency and economics of tropical and temperate options. Crop and Pasture Science 63, 819-832. doi:10.1071/CP12190

Bell LW, Hayes RC, Pembleton KG, Waters CM (2014) Opportunities and challenges in Australian grasslands: pathways to achieve future sustainability and productivity imperatives. Crop and Pasture Science 65, 489-507. doi:10.1071/CP13420

Beutel TS, Tindall D, Denham R, Trevithick R, Scarth P, Abbott B, Holloway C (2014) Getting ground cover right: thresholds and baselines for a healthier reef. Report to the Reef Rescue Research and Development Program. Reef and Rainforest Research Centre Limited, Cairns, Qld. $64 \mathrm{pp}$.

BOM (Bureau of Meteorology) (2014) Climate Data Online. Available at http://www.bom.gov.au/climate/data/index.shtml [Verified November 2014]

Bourne GF, Tuck GA (1993) 'Understanding and managing soils in the Central Highlands.' (Eds RN Thwaites, JM Maher) (Department or Primary Industries: Brisbane, Qld)

Bowen MK, Buck SR, Gowen RL (2010) 'High-output forage systems for meeting beef markets - Phase 1.' Project B.NBP.0496 Final Report. (Meat and Livestock Australia: North Sydney)

Bowen M, Buck S, Chudleigh F (2015a) 'Feeding forages in the Fitzroy. A guide to profitable beef production in the Fitzroy River catchment.' (State of Queensland, Department of Agriculture and Fisheries: Brisbane, Qld)

Bowen MK, Chudleigh F, Buck S, Hopkins K, Brider J (2015b) 'High-output forage systems for meeting beef markets - Phase 2.' Project B.NBP.0636 Final Report. (Meat and Livestock Australia: Sydney)

Chataway RG, Cooper JE, Orr WN, Cowan RT (2011a) The role of tillage, fertiliser and forage species in sustaining dairying based on crops in southern Queensland 2. Double-crop and summer sole-crop systems. Animal Production Science 51, 904-919. doi:10.1071/AN11032

Chataway RG, Orr WN, Cooper JE, Cowan RT (2011b) The role of tillage, fertiliser and forage species in sustaining dairying based on crops in southern Queensland 1. Winter-dominant forage systems. Animal Production Science 51, 890-903. doi:10.1071/AN11028

Clem RL (2004) Animal production from legume-based ley pastures in southeastern Queensland. In 'Tropical legumes for sustainable farming systems in southern Africa and Australia'. ACIAR Proceedings No. 115. (Eds AM Whitbread, BC Pengelly) pp. 136-144. (ACIAR: Canberra)

Coates DB (2004) Faecal NIRS - technology for improving nutritional management of grazing cattle. Final Report of Project NAP3.121 to Meat and Livestock Australia, Sydney.

Coates DB, Dixon DB (2011) Developing robust faecal near infrared spectroscopy calibrations to predict diet dry matter digestibility in cattle consuming tropical forages. Journal of Near Infrared Spectroscopy 19, 507-519. doi:10.1255/jnirs. 967

Delgado CL, Narrod CA, Tiongco MM (2008) 'Determinants and implications of the growing scale of livestock farms in four fastgrowing developing countries.' Research Report 157, International Food Policy Research Institute. (International Food Policy Research Institute: Washington, DC) $131 \mathrm{pp}$.

Dixon RM, Coates DB (2009) Near infrared spectroscopy of faeces to evaluate the nutrition and physiology of herbivores. A review. Journal of Near Infrared Spectroscopy 17, 1-31. doi:10.1255/jnirs.822

Donaghy P, Gowen R, Star M, Murphy K, Sullivan M, Best M (2010) 'Strategies to improve the profitability of extensive grazing systems in central Queensland.' (The State of Queensland, Department of Employment, Economic Development and Innovation: Brisbane, Qld)

Dove H, McLennan SR, Poppi DP (2010) Application of nutrient requirement schemes to grazing animals. In 'Proceedings of the 4th grazing livestock nutrition conference'. Estes Park, USA. 9-10 July 2010. (Eds BW Hess, T DelCurto, JGP Bowman, RC Waterman) pp. 133-149. (Western Section American Society of Animal Science: Champaign, IL)

DPI\&F (The State of Queensland, Department of Primary Industries and Fisheries) (2005) 'The butterfly pea book: a guide to establishing and managing butterfly pea pastures in central Queensland.' (Eds R Collins, T Grundy) (State of Queensland, Department of Primary Industries: Brisbane)

Gillespie RL, Shields PG, Cannon RS (1991) 'Land management manual Dawson/Callide Districts.' (Ed. JA Elsol) (Queensland Department of Primary Industries: Brisbane, Qld)

Gowen R, Donaghy P, Sullivan M (2009) 'Queensland beef industry economic performance.' (The State of Queensland, Department of Employment, Economic Development and Innovation: Brisbane Qld)

Hajkowicz S, Eady S (2015) 'Rural Industry Futures: megatrends impacting Australian agriculture over the coming twenty years.' Publication No. 15/065. Project no. PRJ-009712. (Rural Industries Research and Development Corporation: Barton, ACT) 107 pp.

Hill JO, Coates DB, Whitbread AM, Clem RL, Robertson MJ, Pengelly BC (2009) Seasonal changes in pasture quality and diet selection and their relationship with liveweight gain of steers grazing tropical grass and grass-legume pastures in northern Australia. Animal Production Science 49, 983-993. doi:10.1071/EA06331

Hunt L, Ash A, MacLeod ND, McDonald CK, Scanlon J, Bell LW, Cowley R, Watson I, McIvor J (2014) 'Research opportunities for sustainable productivity improvement in the northern beef industry: a scoping study.' Project B.BSC.0107 Final Report. (Meat and Livestock Australia: North Sydney)

Jones RJ, Ludlow MM, Throughton JH, Blunt CG (1979) Estimation of the proportion of $\mathrm{C}_{3}$ and $\mathrm{C}_{4}$ plant species in the diets of animals from the ratio of natural ${ }^{12} \mathrm{C}$ and ${ }^{13} \mathrm{C}$ isotopes in the faeces. The Journal of Agricultural Science 92, 91-100. doi:10.1017/S0021859600060536

Keating BA, Carberry PS, Hammer GL, Probert ME, Robertson MJ, Holzworth D, Huth NI, Hargreaves JNG, Meinke H, Hochman Z, McLean G, Verburg K, Snow V, Dimes JP, Silburn M, Wang E, 
Brown S, Bristow KL, Asseng S, Chapman S, McCown RL, Freebairn DM, Smith CJ (2003) An overview of APSIM, a model designed for farming systems simulation. European Journal of Agronomy 18, 267-288. doi:10.1016/S1161-0301(02)00108-9

McCosker T, McLean D, Holmes P (2010) 'Northern beef situation analysis 2009.' Project B.NBP.0518 Final Report. (Meat and Livestock Australia Limited: North Sydney)

McCown RL, Hammer GL, Hargreaves JNG, Holzworth DP, Freebairn DM (1996) APSIM: a novel software system for model development, model testing and simulation in agricultural systems research. Agricultural Systems 50, 255-271. doi:10.1016/0308-521X(94)00055-V

McLean I, Holmes P, Counsell D (2014) 'The northern beef report. 2013 northern beef situation analysis.' Project B.COM.0348 Final Report. (Meat and Livestock Australia Limited: North Sydney)

McLennan SR (2014) 'Optimising growth paths of beef cattle in northern Australia for increased profitability.' Project B.NBP.0391 Final Report. (Meat and Livestock Australia: North Sydney)

McLennan SR, Poppi DP (2005) 'Improved prediction of the performance of cattle in the tropics.' Project NBP.331 Final Report. (Meat and Livestock Australia: North Sydney)

Mott JJ, Tothill JC (1984) Tropical and sub-tropical woodlands. In 'Management of Australia's rangelands'. (Eds GN Harrington, AD Wilson, MD Young) pp. 255-270. (CSIRO Publishing: Melbourne)

Muldoon DK (1985) Summer forages under irrigation. 1. Growth and development. Australian Journal of Experimental Agriculture 25, 392-401. doi:10.1071/EA9850392

Muldoon DK (1986) Dry matter accumulation and changes in forage quality during primary growth and three regrowths of irrigated winter cereals. Australian Journal of Experimental Agriculture 26, 87-98. doi:10.1071/ EA9860087

Myers R, Robbins G (1991) Sustaining productive pastures in the tropics. 5. Maintaining productive sown grass pastures. Tropical Grasslands 25, 104-110.

Norman HC, Wilmot MG, Thomas DT, Masters DG, Revell DK (2009) Stable carbon isotopes accurately predict diet selection by sheep fed mixtures of $\mathrm{C}_{3}$ annual pastures and saltbush or $\mathrm{C}_{4}$ perennial grasses. Livestock Science 121, 162-172. doi:10.1016/j.livsci.2008.06.005

Peck GA, Buck SR, Hoffman A, Holloway C, Johnson B, Lawrence DN, Paton CJ (2011) 'Review of productivity decline in sown grass pastures.' Project B.NBP.0624 Final Report. (Meat and Livestock Australia Limited: Sydney)

Peck G, Hoffman A, Johnson B (2012) Legumes are the best option for improving returns from sown pastures in northern Australia. In 'Proceedings of the Australian Legume Symposium'. Australian Grasslands Association Research Association Series No. 1. (Ed. C Harris) p. 13. (Australian Grasslands Association: Melbourne)

Peck G, Chudleigh F, Guppy C, Johnson B, Lawrence D (2015) 'Use of phosphorus fertiliser for increased productivity of legume-based sown pastures in the Brigalow Belt region - a review.' Project B.NBP.0769 Final Report. (Meat and Livestock Australia: Sydney)

Phillips WA, Horn GW, Cole NA (2011) The relevancy of forage quality to beef production. Crop Science 51, 410-419. doi:10.2135/cropsci 2010.06.0382

Rayment GE, Lyons DJ (2011) 'Soil chemical methods.' (CSIRO Publishing: Melbourne)

Shelton M, Dalzell S (2007) Production, economic and environmental benefits of leucaena pastures. Tropical Grasslands 41, 174-190.

Sweeney RA (1989) Generic combustion method for determination of crude protein in feeds. Journal - Association of Official Analytical Chemists 72, 770-774.

Tothill JC, Gillies CC (1992) 'The pasture lands of northern Australia: their condition, productivity and sustainability.' Occasional Publication No. 5. (Tropical Grasslands Society of Australia: Brisbane)

Tothill JC, Hargreaves JNG, Jones RM, McDonald CK (1992) 'BOTANAL: a comprehensive sampling technique for estimating pasture yield and composition. 1. Field Sampling.' Tropical Agronomy Technical Memorandum No. 78. (CSIRO Division of Tropical Crops and Pastures: Brisbane) 